"Bushmen" may argue that the marks were those of the "hind foot" of a " tiger," which has only four toes, though few bushmen probably know it; but I reply that in the four-toed hind foot of a thylacine the whole "sole" of the foot goes on to the ground. I advise Mr. Scott " to give it up," and catch the roaring tiger first before he puts the society to further expense in illustrating " footprints of dog's feet.”

\title{
Preliminary Descriptions of three new Species of Cetacea from the
} Coast of California. By W. H. DALL, U. S. Coast Survey.

\section{Delphinus Bairdii, n. sp.}

Back, posterior sides, fins, and flukes black; anterior sides grey, with two narrow white lateral stripes; a white lanceolate bellypatch. Dorsal falcate; beak slender, elongated. Length 6 feet 7 inches to $6 \mathrm{ft} .9 \mathrm{in}$. Length of skull $18 \cdot 76 \mathrm{in}$.; length of beak before the notches 11.9 in.; height of skull at vertex 6 in.; greatest breadth at zygomatic process of squamosals 6.95 in.; breadth between maxillary notches $3 \cdot 4$ in., ditto at middle of beak 2 in. Teeth $\frac{53}{4} \frac{3}{7}$, the anterior six on each side very small, not projecting above the gums.

Two female specimens, Cape Arguello, California (Scammon, 1872), of which one entire skeleton has been forwarded to the National Museum at Washington.

This species belongs to the restricted genus Delphinus of Gray, and is peculiar from its extremely attenuated beak and very deep channels on each side of the palate behind. The superior aspect of the skull resembles that of Clymenia microps, Gray. It differs from all the described species of the genus in colour and osteological characters, and will be fully described in the fortheoming monograph of the Pacific Cetacea by Capt. C. M. Scammon, U.S.R.M., to whom I am indebted for the opportunity of describing this and the following species. It is dedicated, by request of Capt. Scammon, to Prof. S. F. Baird, of the Smithsonian Institution.

\section{Tursiops Gillii, n. sp.}

Dull black, lighter on the belly. Dorsal low, falcate. Teeth $\frac{\rho 23}{22}$.

Monterey, California.

Lower jaw : length from end of beak to condyles $16 \cdot 8$ in., ditto to end of coronoid process $15.8 \mathrm{in}$., ditto to end of tooth-line $9 \cdot 3 \mathrm{in}$.; length of symphysis $2 \mathrm{in}$; ; width between outer edges of condyles $9 \cdot 75$ in., between two posterior teeth 3.5 in.; height of ramus at coronoid process $4 \cdot 4$ in.

The material for identification of this species is unfortunately very small, being only the lower jaw and outlines of the animal drawn by Capt. Scammon. It does not appear to have been described; and the only other species of the genus described from the Pacific is the T. catalania, Gray, from N.W. Australia, which is described as being lead-coloured. It is dedicated to Prof. Theodore Gill, of the Smithsonian Institution, whose memoirs on the Cetacea and Pinnipedia of the Pacific are already classical, by desire of Capt. Scammon. 


\section{Grampus Stearnsii, n.sp.}

Colours dark, but variable ; the anterior portion of the body white, and the sides of the body more or less mottled with grey. Dorsal high and slightly falcate. Animal 12 or 15 feet long; teeth $\frac{0}{3}$ or $\frac{0}{4}$. Coast of California.

Two lower jaws of this animal are in my hands for examination; and, but that no Grampus has been described from the Pacific, I should hesitate about applying a specific name to them. Gray has, indeed, catalogued a Grampus (?) sakamata (!) from Japan, based on a Japanese account quoted by Schlegel; but the genus is by no means certain, the descriptions are conflicting, and the species rests on no scientific basis. The jaws referred to are attributed by Captain Scammon to his " white-headed grampus," and measure from the end of the beak to the condyles $17 \cdot 5$ in., ditto to coronoid process 16.2 in.; height of ramus at coronoid process 5 in. ; length of symphysis 2 in.; height of gonys 2 in.; width between outer corners of condyles 14 in., ditto at inferior dental foramen 7 in. Teeth in one specimen three, and in the other four on each side near the tip, pointed, solid, shaped like an orange-seed, and extending forward and outward.

Fuller descriptions of this and the last species will be given in the work referred to. The present species is dedicated, by Capt. Scammon's wish, to Mr. R. E. C. Stearns of San Francisco, well known for his researches in natural history.-Proceedings of the California Academy of Sciences, Jan. 29, 1873.

\section{On Hypermetamorphosis in Palingenia virgo, and on the Analogies} of its Larva with the Crustacea. By M. N. JoLr.

M. Joly has ascertained that the larva of Palingenia virgo, when just hatched, has no visible nervous system, no circulatory apparatus, and no organs of respiration. The antennæ and the caudal setæ have not yet the number of joints or the villosity which they will afterwards acquire. The branchiæ appear at a subsequent period in the form of little tubular cæca placed at the posterior angles of the first six segments of the abdomen. These tubular branchiæ afterwards become converted into membranous expansions, which act not only as organs of respiration, but also as very powerful locomotive organs. The circulation, which had at first manifested itself as a simple oscillation of the blood, becomes perfected, and the contractions of the dorsal vessel become very visible.

These facts have probably the merit of novelty as regards the species under investigation; but the author is mistaken in supposing them to be new in the history of insects. M. Joly seems to be ignorant of the memoirs on the development of insects which have been published out of France during the last ten years. Especially he was unacquainted with the remarkable observations of Sir John Lubbock on Chloëon dimidiatum, an Ephemeride nearly allied to Palingenia virgo. The English naturalist has described in the greatest detail the numerous moults of the larva, the increase in 


\section{$2 \mathrm{BHL}$ Biodiversity Heritage Library}

Dall, William Healey. 1873. "Preliminary descriptions of three new species of Cetacea from the coast of California." The Annals and magazine of natural history; zoology, botany, and geology 11, 316-317. https://doi.org/10.1080/00222937308696820.

View This Item Online: https://www.biodiversitylibrary.org/item/81041

DOI: https://doi.org/10.1080/00222937308696820

Permalink: https://www.biodiversitylibrary.org/partpdf/62691

\section{Holding Institution}

Smithsonian Libraries

\section{Sponsored by}

Smithsonian

\section{Copyright \& Reuse}

Copyright Status: Public domain. The BHL considers that this work is no longer under copyright protection.

This document was created from content at the Biodiversity Heritage Library, the world's largest open access digital library for biodiversity literature and archives. Visit BHL at https://www.biodiversitylibrary.org. 